\title{
Non-differential misclassification of exposure always leads to an underestimate of risk: an incorrect conclusion
}

\author{
Tom Sorahan, Mark S Gilthorpe
}

In most epidemiological surveys, there will be some errors of measurement or classification of exposure. For example, for a binary exposure variable, some exposed subjects may be classified as non-exposed, and some nonexposed subjects may be classified as exposed. Non-differential misclassification of exposure is present if, irrespective of disease, all exposed and non-exposed subjects have the same probability of being misclassified (these two probabilities may be different, one must be not zero).

It is now commonplace to find statements in epidemiological textbooks, journal articles, and teaching materials to the effect that nondifferential misclassification of exposure always leads to an underestimate of risk. Rothman, for example, states that "such misclassification can introduce a bias, but the bias is always in the direction of underestimating the effect", 1 and Checkoway et al state "nondifferential misclassification of exposure will bias the effect estimate toward the null value". ${ }^{2}$ This contradicts our expectation that studies may overestimate as well as underestimate effects, and we therefore tested these ideas by computer simulations relevant to study settings.

Each simulation (trial or study) involved a population comprising 5000 exposed and 5000 non-exposed subjects. Exposed subjects each had the same probability $r_{1}$ of becoming diseased within a short time period; for nonexposed subjects the probability was $r_{2}$ (rate ratio $=$ relative risk $\left.=r_{1} / r_{2}\right)$. Also, exposed subjects each had the probability $P_{1}$ of being misclassified; for non-exposed subjects the probability was $P_{2}$. The simulation was performed by a computer program in which a random process was used to classify the out- come of each probability. Two point estimates of relative risk were provided by each simulation: the apparent (or observed) relative risk based on disease events in populations for which misclassification is present, and the actual relative risk based on disease events in the populations if all subjects were correctly classified. Both these estimates were compared, in turn, with the underlying (or true) relative risk set within the computer program.

For each set of initial values for the four parameters $r_{1}, r_{2}, P_{1}$ and $P_{2}, 5000$ independent simulations were carried out (table 1). Columns 1-7 summarise the input data and columns 8-10 summarise the results or output. The first three sets of simulations investigate the effects of misclassification in exposed or non-exposed subjects only, as opposed to being present with equal probability in both groups. Sets 4-6 show the effects of increasing the probability of misclassification, although disease risk remains constant. Sets 7-9 show the effects of increasing the probability of disease, although misclassification probability remains constant.

Column 8 shows that if misclassification had not been present, the simulated studies would have overestimated the relative risk about as often as they underestimated it. Column 9 shows the percentage of simulated studies, with misclassification present, which provided an apparent relative risk $>1.5$. These results indicate that studies affected by non-differential misclassification of exposure will underestimate risks more often than they overestimate risks and that this effect becomes more pronounced as the extent of misclassification is increased (sets 4-6) or when the baseline risk of disease is increased (sets 7-9). Interpretation is assisted by examination of

Table 1 Relative risks obtained from simulated cohort studies with various degrees of non-differential misclassification of exposure

\begin{tabular}{|c|c|c|c|c|c|c|c|c|c|c|}
\hline Set & Simulations & $\begin{array}{l}\text { Exposed } \\
\text { subjects } \\
(n)\end{array}$ & $\begin{array}{l}3 \\
\text { Risk of disease } \\
\text { for exposed } \\
\text { subjects } \\
\left(r_{\nu}\right)\end{array}$ & $\begin{array}{l}\text { Non-exposed } \\
\text { subjects } \\
(n)\end{array}$ & $\begin{array}{l}5 \\
\text { Risk of disease } \\
\text { for non-exposed } \\
\text { subjects } \\
\left(r_{2}\right)\end{array}$ & $\begin{array}{l}6 \\
\text { Probability } \\
\text { that exposed } \\
\text { subjects are } \\
\text { misclassified } \\
\left(P_{\nu}\right)\end{array}$ & $\begin{array}{l}7 \\
\text { Probability that } \\
\text { non-exposed } \\
\text { subjects are } \\
\text { misclassified } \\
\left(P_{\nu}\right)\end{array}$ & $\begin{array}{l}8 \\
\text { Simulations } \\
\text { for which } \\
R R \text { (actual) } \\
>1 \cdot 5 \\
(\%)\end{array}$ & $\begin{array}{l}9 \\
\text { Simulations } \\
\text { for which } \\
R R \text { (apparent) } \\
>1 \cdot 5 \\
(\%)\end{array}$ & $\begin{array}{l}10 \\
\text { Simulations } \\
\text { for which } \\
R R \text { (apparent) } \\
>R R \text { (actual) } \\
(\%)\end{array}$ \\
\hline $\begin{array}{l}1 \\
2 \\
3\end{array}$ & $\begin{array}{l}5000 \dagger \\
5000 \\
5000\end{array}$ & $\begin{array}{l}5000 \\
5000 \\
5000\end{array}$ & $\begin{array}{l}0.0075 \\
0.0075 \\
0.0075\end{array}$ & $\begin{array}{l}5000 \\
5000 \\
5000\end{array}$ & $\begin{array}{l}0.0050 \\
0.0050 \\
0.0050\end{array}$ & $\begin{array}{l}0 \cdot 1 \\
0 \cdot 2 \\
0 \cdot 0\end{array}$ & $\begin{array}{l}0 \cdot 1 \\
0 \cdot 0 \\
0 \cdot 2\end{array}$ & $\begin{array}{l}49 \cdot 82 \\
48.34 \\
50.12\end{array}$ & $\begin{array}{l}36 \cdot 22 \\
38 \cdot 22 \\
41 \cdot 82\end{array}$ & $\begin{array}{l}28 \cdot 82 \\
33 \cdot 78 \\
34 \cdot 08\end{array}$ \\
\hline $\begin{array}{l}4 \\
5 \\
6\end{array}$ & $\begin{array}{l}5000 \dagger \\
5000 \\
5000\end{array}$ & $\begin{array}{l}5000 \\
5000 \\
5000\end{array}$ & $\begin{array}{l}0.0075 \\
0.0075 \\
0.0075\end{array}$ & $\begin{array}{l}5000 \\
5000 \\
5000\end{array}$ & $\begin{array}{l}0.0050 \\
0.0050 \\
0.0050\end{array}$ & $\begin{array}{l}0 \cdot 1 \\
0 \cdot 2 \\
0 \cdot 3\end{array}$ & $\begin{array}{l}0 \cdot 1 \\
0 \cdot 2 \\
0 \cdot 3\end{array}$ & $\begin{array}{l}49 \cdot 75 \\
49.12 \\
50.52\end{array}$ & $\begin{array}{l}37 \cdot 24 \\
27 \cdot 44 \\
17 \cdot 18\end{array}$ & $\begin{array}{l}29 \cdot 62 \\
25 \cdot 68 \\
19 \cdot 20\end{array}$ \\
\hline $\begin{array}{l}7 \\
8 \\
9\end{array}$ & $\begin{array}{l}5000 t \\
5000 \\
5000\end{array}$ & $\begin{array}{l}5000 \\
5000 \\
5000\end{array}$ & $\begin{array}{l}0.0075 \\
0.0375 \\
0.0750\end{array}$ & $\begin{array}{l}5000 \\
5000 \\
5000\end{array}$ & $\begin{array}{l}0.0050 \\
0.0250 \\
0.0500\end{array}$ & $\begin{array}{l}0 \cdot 1 \\
0 \cdot 1 \\
0 \cdot 1\end{array}$ & $\begin{array}{l}0 \cdot 1 \\
0 \cdot 1 \\
0 \cdot 1\end{array}$ & $\begin{array}{l}49 \cdot 48 \\
50.00 \\
49.56\end{array}$ & $\begin{array}{l}36 \cdot 46 \\
19 \cdot 46 \\
11 \cdot 08\end{array}$ & $\begin{array}{l}29 \cdot 34 \\
9 \cdot 94 \\
2 \cdot 94\end{array}$ \\
\hline
\end{tabular}

* Underlying (or true) relative risk set within the computer program to be 1.5 ; $R R$ (actual) = relative risk provided by the simulation if all misclassification of exposure is removed; RR (apparent) = relative risk provided by the simulation with misclassification present (apparent relative risk).

exposure is removed; $R R$ (apparent) $=$ relative risk provided by the simulation with misclas are obtained because each row summarises independent sets of 5000 simulations. 
Table 2 Ranges of the relative risk obtained from simulated cohort studies with various degrees of non-differential misclassification of exposure

\begin{tabular}{|c|c|c|c|c|c|c|c|c|c|}
\hline \multirow[b]{2}{*}{$\mathrm{Set}^{*}$} & \multicolumn{3}{|l|}{$R R$ (actual) } & \multicolumn{3}{|l|}{$R R$ (apparent) } & \multicolumn{3}{|c|}{$R R$ (apparent)-RR (actual) } \\
\hline & 5th Percentile & Median & 95th Percentile & 5th Percentile & Median & 95th Percentile & 5th Percentile & Median & 95th Percentile \\
\hline $\begin{array}{l}1 \\
2 \\
3\end{array}$ & $\begin{array}{l}0.97 \\
0.97 \\
0.97\end{array}$ & $\begin{array}{l}1.50 \\
1.52 \\
1.50\end{array}$ & $\begin{array}{l}2 \cdot 35 \\
2 \cdot 37 \\
2 \cdot 33\end{array}$ & $\begin{array}{l}0.90 \\
0.92 \\
0.92\end{array}$ & $\begin{array}{l}1.37 \\
1.42 \\
1.40\end{array}$ & $\begin{array}{l}2 \cdot 12 \\
2 \cdot 30 \\
2 \cdot 13\end{array}$ & $\begin{array}{l}-0.62 \\
-0.46 \\
-0.59\end{array}$ & $\begin{array}{l}-0.13 \\
-0.09 \\
-0.09\end{array}$ & $\begin{array}{l}0 \cdot 28 \\
0.33 \\
0 \cdot 28\end{array}$ \\
\hline $\begin{array}{l}4 \\
5 \\
6\end{array}$ & $\begin{array}{l}0.97 \\
0.97 \\
1.00\end{array}$ & $\begin{array}{l}1.50 \\
1.50 \\
1.52\end{array}$ & $\begin{array}{l}2 \cdot 35 \\
2 \cdot 35 \\
2 \cdot 35\end{array}$ & $\begin{array}{l}0.90 \\
0.85 \\
0.76\end{array}$ & $\begin{array}{l}1 \cdot 38 \\
1 \cdot 28 \\
1 \cdot 17\end{array}$ & $\begin{array}{l}2 \cdot 18 \\
1.97 \\
1 \cdot 80\end{array}$ & $\begin{array}{l}-0.59 \\
-0.86 \\
-1 \cdot 10\end{array}$ & $\begin{array}{l}-0.12 \\
-0.20 \\
-0.33\end{array}$ & $\begin{array}{l}0 \cdot 27 \\
0 \cdot 33 \\
0 \cdot 29\end{array}$ \\
\hline $\begin{array}{l}7 \\
8 \\
9\end{array}$ & $\begin{array}{l}1.00 \\
1.24 \\
1.31\end{array}$ & $\begin{array}{l}1.50 \\
1.50 \\
1.50\end{array}$ & $\begin{array}{l}2.35 \\
1.81 \\
1.71\end{array}$ & $\begin{array}{l}0.90 \\
1 \cdot 14 \\
1 \cdot 20\end{array}$ & $\begin{array}{l}1.37 \\
1.36 \\
1.36\end{array}$ & $\begin{array}{l}2 \cdot 14 \\
1.64 \\
1.55\end{array}$ & $\begin{array}{l}-0.61 \\
-0.32 \\
-0.26\end{array}$ & $\begin{array}{l}-0.12 \\
-0.13 \\
-0.14\end{array}$ & $\begin{array}{r}0.27 \\
0.03 \\
-0.02\end{array}$ \\
\hline
\end{tabular}

ॠThese results refer to the simulations described in table 1 .

the ranges of actual and apparent relative risk (table 2). For example, the three variable ranges are all narrower for set 9 than for set 7 . This is a consequence of simulations in set 9 having an expectation of 250 disease events in non-exposed subjects, whereas the corresponding expectation for simulations in set 7 was only 25 events.

More importantly, the results shown in column 10 (table 1) indicate that an appreciable percentage of studies with non-differential misclassification present will produce risk estimates that are larger than if the data were reclassified correctly. For example, set 1 summarises simulations in which exposed and non-exposed subjects each had a one in 10 chance of being misclassified; $28 \%$ produced point estimates larger than the corresponding relative risks if all misclassification were to be removed. The earlier claims are therefore incorrect. They were based on a misleading illustration because both disease outcome and exposure misclassification were assumed to operate on a proportionate rather than a random basis. Results from sets 7-9 indicate that for a given study cohort there is a reduced chance of non-differential misclassification overestimating relative risk if the disease is more common.

Some investigators have convinced themselves that, so long as exposure data have been collected blind to any knowledge of disease, random misclassification of data is not an issue in studies that show an effect. An earlier statement of Case et al might be more helpful-namely that, "the accuracy of any statistical analysis is limited by the accuracy of the information upon which it is based". ${ }^{3}$ (This note has been concerned solely with the properties of non-differential misclassification. In practice, study subjects will rarely have the same probability of being misclassified and differential misclassification will often present the more important exposure assessment problem.)

1 Rothman KJ. Modern epidemiology. Boston: Little Brown, 1986:88.

2 Checkoway H, Pearce NE, Crawford-Brown DJ. Research methods in epidemiology. Oxford: Oxford University Press, 1989:80.

3 Case RAM, Hosker ME, McDonald DB, Pearson JT. Tumours of the urinary bladder in workmen engaged in the manufacture and use of certain dyestuff intermediates in the British chemical industry. $\mathrm{Br} F$ Ind $\mathrm{Med}$ 1954;11:75-105.

\section{Instructions to authors}

Three copies of all submissions should be sent to: The Editor, Occupational and Environmental Medicine, BMJ Publishing Group, BMA House, Tavistock Square, London WC1H 9JR, UK. All authors should sign the covering letter as evidence of consent to publication. Papers reporting results of studies on human subjects must be accompanied by a statement that the subjects gave written, informed consent and by evidence of approval from the appropriate ethics committee. These papers should conform to the principles outlined in the Declaration of Helsinki (BMf 1964; ii:177).
If requested, authors shall produce the data on which the manuscript is based, for examination by the Editor.

Authors are asked to submit with their manuscript the names and addresses of three people who they consider would be suitable independent reviewers. They will not necessarily be approached to review the paper.

Papers should include a structured abstract of not more than 300 words, under headings of Objectives, Methods, Results, and Conclusions. Please include up to three keywords or key terms to assist with indexing. 